\title{
Piotr $\dot{Z} \mathbf{u k} *$
}

University of Wrocław

\section{EUROPEAN INTEGRATION \\ FROM THE PERSPECTIVE OF EASTERN EUROPEAN SEMI-PERIPHERIES OF THE EUROPEAN UNION. CASE STUDY ON POLAND}

\begin{abstract}
The article presents various opinions and assessments of Polish society regarding membership in the European Union and its consequences. 2014 marks 10 years since countries from Central-Eastern Europe became a part of the European Union. It is a good opportunity for an afterthought on the role and place of the post-communist countries in today's world order. The author of the article suggests that perspectives of post-colonial theories or the system-world dependence theory can be a useful tool to help understand the state of affairs in the region. It is also indicated by the research studies which demonstrate that the respondents notice a gap between Poland and the standards of Western European countries in all aspects of their lives. It does not only refer to the social sphere, but also to assess the institutional order or civic self-awareness.

In spite of difficulties and crises in such countries as Greece or Portugal within the European Union, Polish society - as shown by the results of the author's research studies - perceives further European integration to be a solution to its own problems.
\end{abstract}

Keywords: system transformation, European integration, semi-peripheral capitalism, East-West, assessment of the European Union

\section{INTRODUCTION}

The more than 10 years which have passed since Poland joined the European Union have not weakened Poles' affinity for the European project. It seems that, as it is generally perceived in the country on the Vistula River, Poland is still perceived as a problem, with Europe as its solution. And though recent years have shown that the EU has been losing its vigour and is fading into the mist of neo-liberal concepts, for Eastern Europeans it still seems to be a progressive project. It is not based only on dreams about the consumption-driven West, but also on their belief that it is simply easier to live "there".

* Corresponding author: Piotr Żuk, Instytut Socjologii, Wydział Nauk Społecznych Uniwersytetu Wrocławskiego, ul. Koszarowa, 51-149 Wrocław; e-mail: pzuk@uni.wroc.pl. 


\section{NO MAN'S LAND AND EUROPEAN SEMI-COLONIES}

To understand the paradox of longing for Western Europe while it is being torn apart by the crisis and cuts in past allowances and social rights - which can be observed in Spain, Greece and Portugal - it is necessary to look at Poland and its place in Europe from a slightly distant perspective. It will enable us to understand why the same processes, which for example from the Swedish perspective are considered as a setback, indicate modernisation and progress from the Polish perspective.

Central-Eastern Europe is not the name of a geographical place (although one can try to define its boundaries: The Elbe River marks its western boundary, the Baltic Sea in the north, the Danube River in the south, and the Dnieper River in the East); it is rather the name of a distinct cultural-civilisational area. According to Jan Sowa (2011: 15): "between the West and the East lies 'no man's land' and a 'vague area'." And, through the countries located within the area are internally diversified by their language, economic standing and social conditions, "a kind of commonly jointed feature makes them approach one another. This feature - just like their peripherality - is relative in its character and could be called "the syndrome of under-development, incompleteness, not-full formation, inferiority or, finally [...] social and cultural immaturity" (Sowa 2011: 17-18).

Applying categories devised by Immanuel Wallerstein, the Polish society and its eastern neighbours are typical peripherals and semi-peripherals of the world-system. The reason for their current situation should be sought for in its distant past when the foundations of early capitalism began to form in Europe.

As Wallerstein (2007: 84) writes on the creation of the world-system: "Often countries with their high military strength $[. .$.$] reached areas where political structures were relatively$ weak. In order to effectively incorporate these areas into the world-system, they were conquered and commanded under colonial regimes. [...] Colonies fulfilled the same functions as sovereign countries did: they guaranteed rights of ownership, determined border crossings, set the principles of political participation (always very limited), implemented decisions on work places and often decided on production to be run (or preferred to be run) in these colonies." And though Poland was not a typical colony like African countries, the entire region of Central and Eastern Europe and its history can be considered from the perspective of post-colonial theories.

Jan Sowa is right when he states that - taking into consideration the enormous amount of factual data - one cannot "negate the fact that a sort of inequality of exchange took place which became consolidated, causing chronic underdevelopment of Central and Eastern Europe. And the countries from within the region have made their attempts to work their way out of it - so far with no full success" (Sowa 2011: 28). This underdevelopment had its roots not only in the archaic social-economic grounds and political-economic dependencies from the central countries in Western Europe but also in its pre-modern 'superstructure'. When in Western Europe new political, social and cultural ideas were formed which paved their way for radical social changes, the Catholic Counter-Reformation triumphed in Poland. It hindered the modernisation of the social system in the $16^{\text {th }}$ and $17^{\text {th }}$ centuries. Poland also gave a wide berth to the European "Enlightenment" as well as all the European social revolutions which 
overthrew rigid social structures in the $19^{\text {th }}$ century. Hence the present economic backwardness goes hand in hand with the cultural conservatism (evidenced by a strong standing of the Catholic Church, no de facto separation of the state and the Church, extensive influence of the church circles over national legislation, etc.).

In the $16^{\text {th }}$ century, while in Western Europe a powerful middle class was emerging, cities and towns were being developed, the first manufactories were being established and trade was flourishing, Poland was dominated by feudal relations. Peasants with their servile status towards the ruling nobility formed the largest social class. Craft developed poorly, as did local manufactories. "There were also relatively small resources of a paid labour force (in the West it was formed by peasants flowing from villages to towns and cities). As craft in Poland developed more poorly than it did in Western Europe, the quality of manufactured goods was lower (and their range smaller). Therefore, the Polish nobility, holding large amounts of money, was the only social group who preferred to purchase imported craft goods" (Sowa 2011: 119-120). These dependencies from the $16^{\text {th }}$ and $17^{\text {th }}$ centuries remained until the $19^{\text {th }}$ century. Today the majority of goods sold in Poland is still produced in countries belonging to the centre of the world-system.

\section{THE EUROPEAN UNION AS A CIVILISATIONAL VEHICLE FOR THE SEMI-PERIPHERIES}

Some observers and supporters of Poland's integration with the European Union in 2004 thought that thanks to the process it would be possible to 'transfer' the civilising experience and achievements of Western Europe to the area of Central-Eastern Europe. Thus, the process of integration with the EU as it was commonly felt was treated not only as a political act but rather as an attempt to make up for this civilisational underdevelopment. Under these circumstances, the wide scope of support of most of Polish society for integration aspirations should not be surprising at all.

The empirical materials for some afterthoughts on Poles' opinions on European integration and its effects come from research studies (applying the CATI method on a representative sample of 1,118 people) conducted in 2014. Respondents to be surveyed were selected randomly (Fig. 1-3) $)^{1}$.

It should be emphasised that in Poland the greatest support for the integration processes has been held by the youngest respondents: the younger the age, the more open to the EU. It is interesting that, taking income into consideration, people with the lowest and the highest levels of income perceive the largest benefits from the European integration (Tabs 1 and 2). In case of people from the lower social classes, surely job opportunities in Western European countries seem to be the largest benefit derived from the Poland's accession to the EU. In turn, for people with the highest income, Poland's presence in the EU provided an access to large consumer markets and unlimited market opportunities. Still in any case, it has not led to any smoothing of the level of incomes, life opportunities or living standards between and among the inhabitants of Western Europe and Poland.

\footnotetext{
The research is conducted under the auspices of the Social Monitoring and Civic Culture Centre in Wrocław.
} 


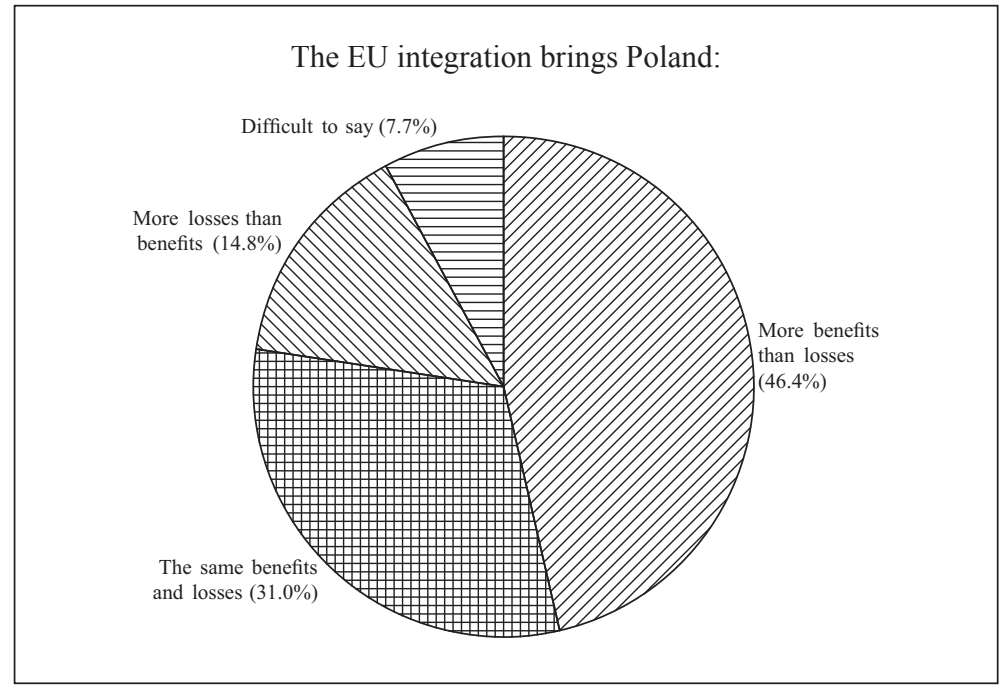

Figure 1. Respondents' assessment of general benefits derived from Poland's integration with the EU, $N=1118$

Table 1. Respondents' support for Poland's integration with the EU - by age and income

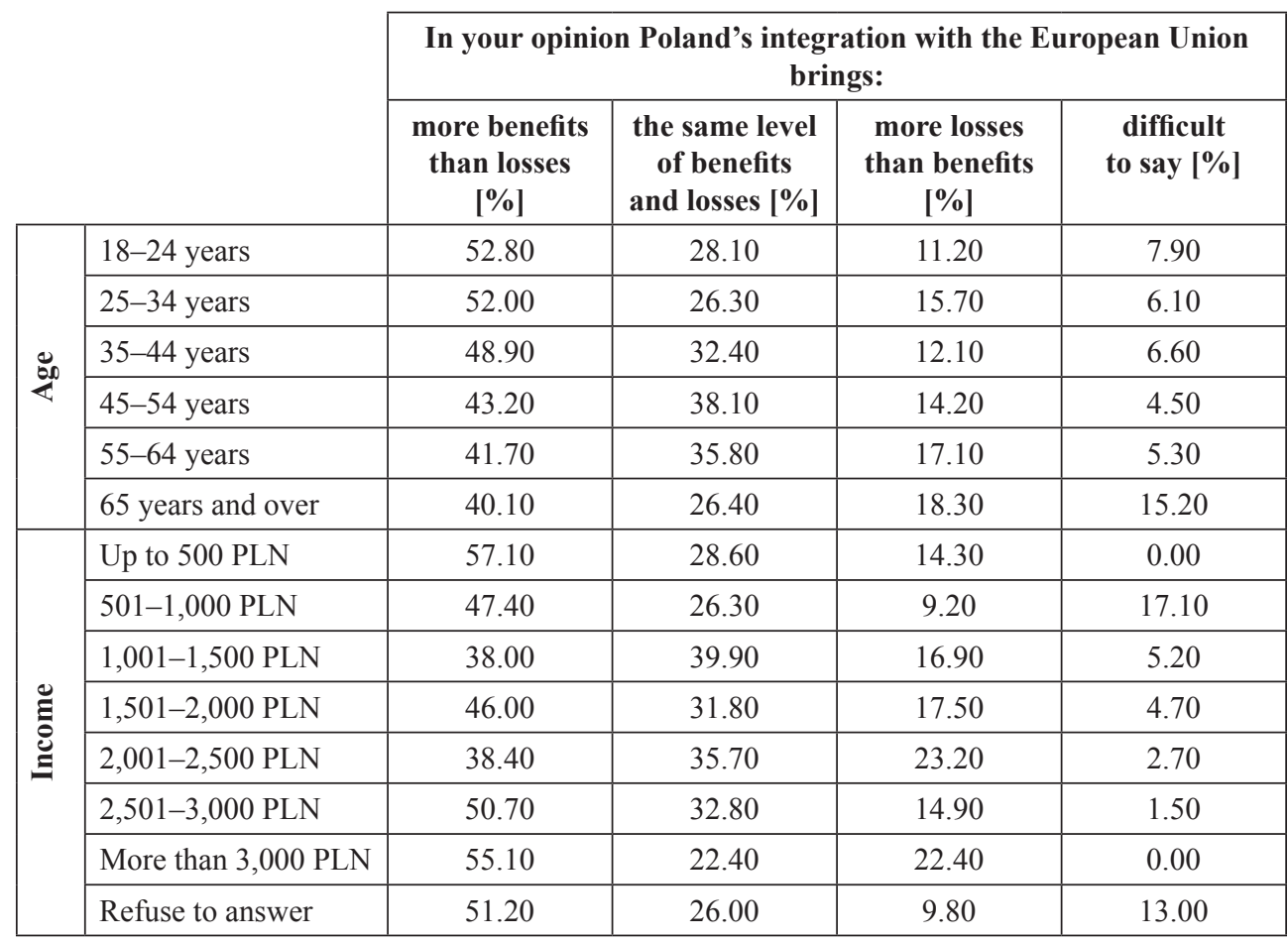


European integration from the perspective of Eastern European semi-peripheries...

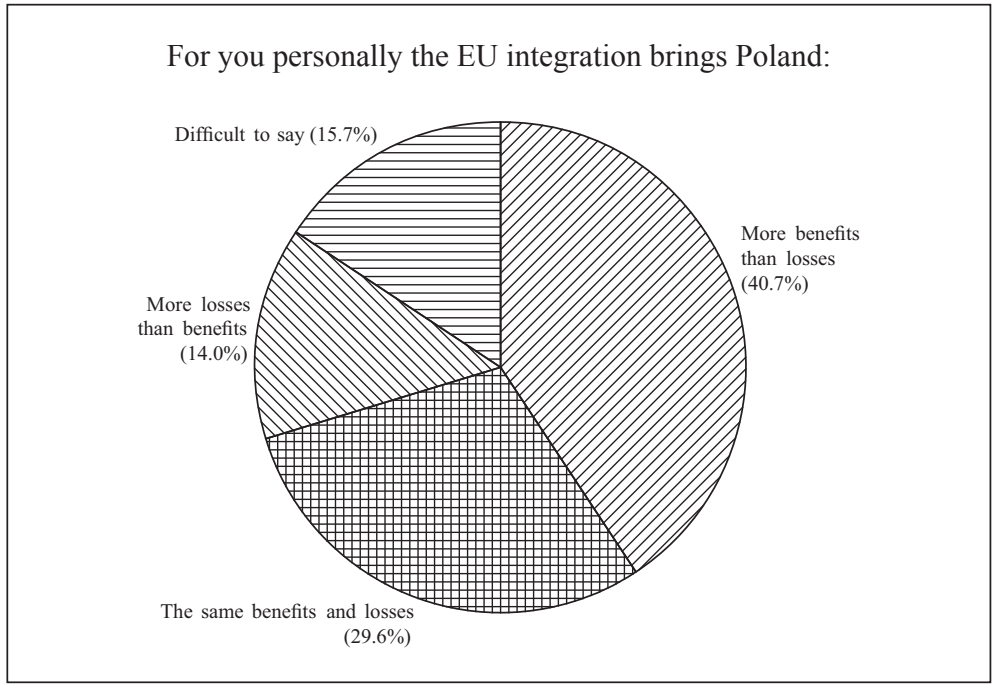

Figure 2. Respondents' assessment of personal benefits derived from Poland's membership in the EU, $N=1118$

Table 2. Respondents' assessment of personal benefits derived from Poland's membership in the EU - by age and income

\begin{tabular}{|c|c|c|c|c|c|}
\hline & \multicolumn{4}{|c|}{$\begin{array}{c}\text { For you personally Poland's integration with the European Union } \\
\text { brings: }\end{array}$} \\
\hline & & $\begin{array}{c}\text { more benefits } \\
\text { than losses } \\
{[\%]}\end{array}$ & $\begin{array}{c}\text { the same level } \\
\text { of benefits } \\
\text { and losses [\%] }\end{array}$ & $\begin{array}{c}\text { more losses } \\
\text { than benefits } \\
{[\%]}\end{array}$ & $\begin{array}{l}\text { difficult } \\
\text { to say }[\%]\end{array}$ \\
\hline \multirow{6}{*}{$\underset{8}{8}$} & $18-24$ years & 51.10 & 24.20 & 9.00 & 15.70 \\
\hline & 25-34 years & 46.50 & 25.30 & 16.20 & 12.10 \\
\hline & $35-44$ years & 49.50 & 24.70 & 12.10 & 13.70 \\
\hline & $45-54$ years & 38.60 & 31.80 & 14.20 & 15.30 \\
\hline & 55-64 years & 31.00 & 39.60 & 14.40 & 15.00 \\
\hline & 65 years and more & 28.40 & 32.00 & 17.30 & 22.30 \\
\hline \multirow{8}{*}{ 苞 } & Up to 500 PLN & 52.40 & 28.60 & 14.30 & 4.80 \\
\hline & 501-1,000 PLN & 32.90 & 28.90 & 5.30 & 32.90 \\
\hline & $1,001-1,500$ PLN & 36.60 & 35.20 & 18.30 & 9.90 \\
\hline & 1,501-2,000 PLN & 43.60 & 31.80 & 16.10 & 8.50 \\
\hline & $2,001-2,500$ PLN & 38.40 & 28.60 & 25.00 & 8.00 \\
\hline & $2,501-3,000$ PLN & 46.30 & 31.30 & 16.40 & 6.00 \\
\hline & Over 3,000 PLN & 57.10 & 20.40 & 16.30 & 6.10 \\
\hline & Refuse to answer & 39.80 & 26.60 & 7.90 & 25.70 \\
\hline
\end{tabular}


The centuries-old disparities cannot be made up for in 25 years (the number of years that have passed since the change of power in Europe) or the several years which have passed since the accession of the Central-Eastern European countries to the EU. All the more, during that time these disparities have not been reduced but persisted and even increased in many spheres of life. Through, among others, the liquidation of the national industry and consequently a large number of jobs, the phenomenon of mass emigration emerged after Poland's accession to the EU. The exact figures of people leaving for work in the Western countries are not known. It is estimated that within the last 10 years about 2-3 million people left the country due to economic reasons. Thus, the dependencies between the Centre and the semi-peripheries have perpetuated. The Polish semi-peripheries have become a sizeable market for products produced in the Centre. In turn, the central countries predominantly import unprocessed natural resources or products which do not require technological investments (agricultural and food products, furniture, wood, vehicles assembled in Poland based on western production-lines) as well as still competitive and cheap labour.

Was any other model of the Polish transformation plausible? As Stieglitz wrote in 1990: "The former socialist countries began their journey having numerous (not just two) paths ahead. [...] At the start of journey made by the former socialist countries it was anticipated that they would be guided not only by narrow economic issues [...] but also by a wider set of ideals which motivated many establishers of socialist traditions. Maybe some of the countries would enter less-travelled paths, which could change not only their lives but also ours" (cf. Kowalik 2010: 63-64). However, that has not been the case. According to Tadeusz Kowalik (2010), who also considers that Poland in 1989 had plentiful opportunities and development potentialities ahead, the most extreme variant of the neo-liberal transformation has in fact been implemented. Professor Grzegorz Kołodko, the former vice prime minister and renowned economist, calls the first period of transformation not shock therapy, but shock without therapy. In his opinion at the time (1989-1992) Poland lost nearly 20 percent of GDP followed by a spike in employment from the zero level up to nearly 3 million people. As Kołodko (2010: 68) says: "doctrinairism and 'taking care' of private affairs displaced economic common sense and consequently the genuine interests of the Polish economy and its business entities were poorly taken care of, which was eagerly exploited by our foreign partners willingly joining our system struggle". These actions resulted in a high level of unemployment, growing social disparities and increasing poverty (Kowalik 2010: 64-66).

On one hand it resulted from the ignorance of the new political elite in Poland, having no adequate knowledge of potential economic models to be implemented, but also from our uncritical faith in the idealised image of capitalism, which was supposed to provide full shelves of attractive products, and colourful shops and advertisements, but - without unemployment, social inequalities and brutal privatisation. On the other hand, upon the collapse of the Eastern Block, Western capital sensed a great opportunity to do business in Central-Eastern Europe and thanks to Western advisers, in the atmosphere of building the foundations of democracy, the economic offensive started. Grzegorz Kołodko put it right when, upon it happening, he wrote:

The Western, declarative concern for the progress and democracy, development and prosperity of post-socialist societies stands for - first and foremost - the rhetoric obscuring private interests of the elites from the rich countries. Not only political interests, but primarily economic and financial 
ones. One should not be offended by this fact - it would be a sin of great naivety if one does not realise it (Kołodko 2010: 64).

Noam Chomsky wrote about it in a more determined manner. He stated that the countries of the former Eastern Bloc were treated like a locomotive which was to pull the process of social dumping and to provide access to unlimited resources of cheap labour:

The potential contributions of Eastern Europe to undermining quality of life for the majority in the West was recognized immediately after the fall of the Berlin Wall. The business press was exultant about the 'green shoots in Communism's ruins,' where 'rising unemployment and pauperization of large sections of the industrial working class' meant that people were willing to 'work longer hours than their pampered colleagues' in the West, at 40 per cent of the wages and with few benefits. Further 'green shoots' include enough repression to keep working people in line and attractive state subsidies for Western investors (Chomsky 2003: 146).

And although relations between the countries of Central-Eastern Europe and the West have not been and are not balanced, it is the West which is still perceived by residents of the post-communist countries as the only realistic modernising force.

For the above reasons, 25 years after the system transformation and more than 10 years after Poland's accession to the EU, the West - though still in crisis - has still been an icon worth heading for. It is not without good reason that many researchers (for example Marek Ziółkowski) called these processes taking place in Poland "imitative modernisation" - they are meant to imitate the West.

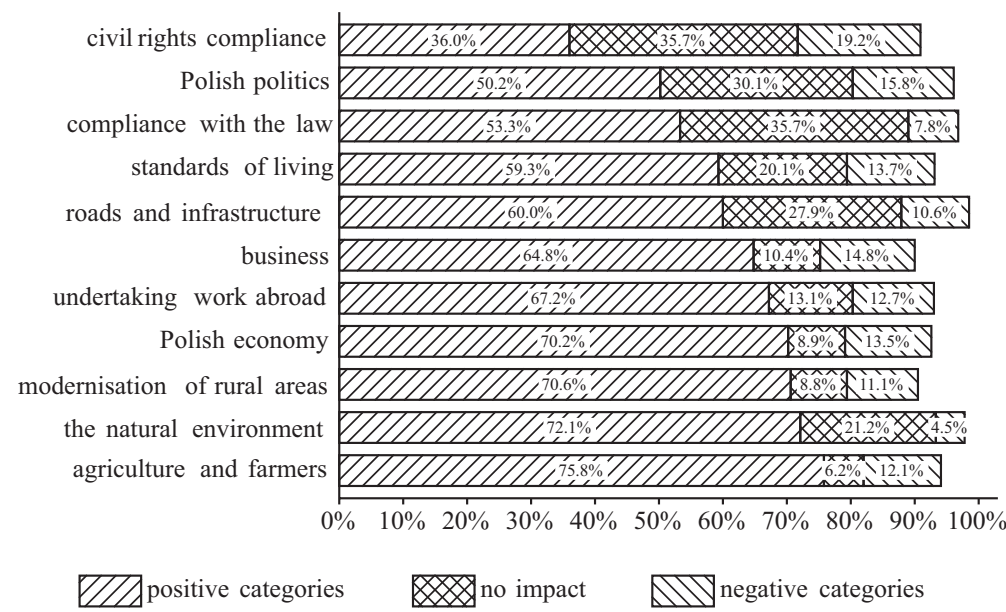

Figure 3. Impact of Poland's integration with the EU on some selected spheres of public life, $N=1118^{*}$

* The results do not add up to $100 \%$ as "difficult to say" responses were not taken under consideration.

The respondents perceived a positive impact of the European Union on functioning of the collective governance in Poland within all spheres of public life. The lowest impact of Poland's 
membership in the EU was observed in the scope of improving civil rights compliance (36\%) and politics (about 50\%). The greatest positive changes - according to the respondents - have taken place in the following areas: Polish agriculture (nearly $76 \%$ of the respondents share this opinion), the natural environment (over $72 \%$ ), modernisation of Polish rural areas $(70.6 \%)$ and the Polish economy (70.2\%).

\section{AGE AND INCOME IN THE ASSESSMENT OF EUROPEAN INTEGRATION AND ITS EFFECTS}

Age is a variable which impacts European attitudes most: the younger the respondent, the more benefits perceived in the process of European integration. Both in terms of the Polish economy and the standard of living, most advantages derived from Poland's presence in the EU are perceived by the respondents from the youngest age groups (Tabs 3 and 5). Interestingly, when assessing the standard of living, most positive changes in this scope are also perceived by the poorest people (income up to $500 \mathrm{PLN}$ net per person/household). In this category up to $76 \%$ of people believed that Poles' standard of living has improved as a consequence of European integration (Tab. 5).

Among the youngest and the middle-aged (up to 44 years) respondents, the most common belief (over $72 \%$ ) is that integration with the EU has led to Poles travelling abroad for work more frequently (Tab. 4). It should not be any surprise at all as in this age category the largest number of people travel abroad for economic reasons. And - as long as the level of wages across the EU does not balance out - this process will continue. It can be assumed that the process will intensify once the new EU members from Central-Eastern Europe no longer receive financial support from the EU budget (this will take place after 2020).

Table 3. Respondents' age and their assessment of the impact of Poland's membership in the EU on the economy

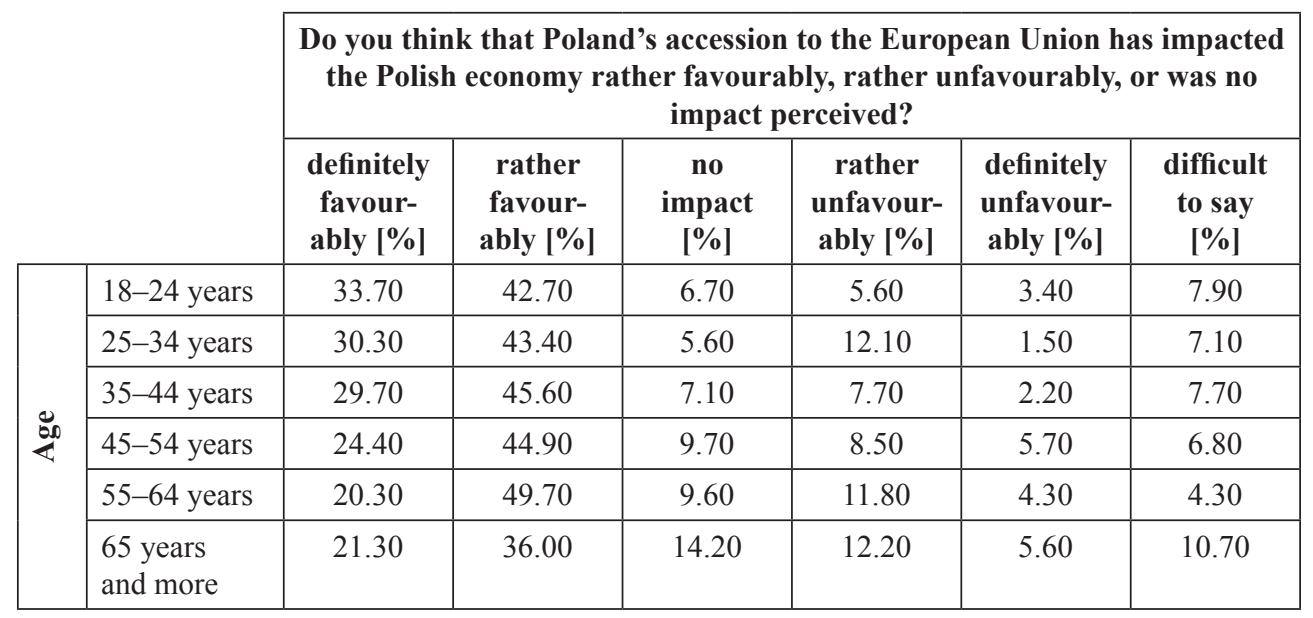


European integration from the perspective of Eastern European semi-peripheries...

Table 4. Respondents' age and their assessment of the impact of Poland's membership in the EU on Poles travelling abroad for work

\begin{tabular}{|c|c|c|c|c|c|c|c|}
\hline & \multicolumn{6}{|c|}{$\begin{array}{l}\text { Do you think that Poland's accession to the European Union has } \\
\text { increased/decreased/not changed the number of Poles undertaking } \\
\text { jobs abroad? }\end{array}$} \\
\hline & & $\begin{array}{l}\text { definitely } \\
\text { increased } \\
{[\%]}\end{array}$ & $\begin{array}{c}\text { rather } \\
\text { increased } \\
{[\%]}\end{array}$ & $\begin{array}{l}\text { no } \\
\text { change } \\
{[\%]}\end{array}$ & $\begin{array}{c}\text { rather } \\
\text { decreased } \\
{[\%]}\end{array}$ & $\begin{array}{c}\text { definitely } \\
\text { decreased } \\
{[\%]}\end{array}$ & $\begin{array}{c}\text { difficult } \\
\text { to say } \\
{[\%]}\end{array}$ \\
\hline \multirow{6}{*}{$\underset{z}{\infty}$} & $18-24$ years & 31.50 & 40.40 & 11.20 & 7.90 & 2.20 & 6.70 \\
\hline & 25-34 years & 24.20 & 50.50 & 10.10 & 10.60 & 0.50 & 4.00 \\
\hline & $35-44$ years & 22.00 & 52.70 & 9.30 & 9.30 & 2.20 & 4.40 \\
\hline & $45-54$ years & 18.20 & 47.70 & 13.10 & 9.10 & 4.00 & 8.00 \\
\hline & 55-64 years & 19.80 & 44.90 & 15.50 & 12.30 & 2.70 & 4.80 \\
\hline & 65 years and more & 15.20 & 36.50 & 18.80 & 11.20 & 4.10 & 14.20 \\
\hline
\end{tabular}

Table 5. Respondents' age and income and their assessment of the impact of Poland's membership in the EU and Poles' standard of living

\begin{tabular}{|c|c|c|c|c|c|c|c|}
\hline & \multicolumn{6}{|c|}{$\begin{array}{l}\text { Do you think that Poland's accession to the European Union has } \\
\text { impacted Poles' standards of living rather favourably, rather } \\
\text { unfavourably or was no impact perceived? }\end{array}$} \\
\hline & & $\begin{array}{l}\text { definitely } \\
\text { favour- } \\
\text { ably }[\%]\end{array}$ & $\begin{array}{l}\text { rather } \\
\text { favour- } \\
\text { ably }[\%]\end{array}$ & $\begin{array}{c}\text { no } \\
\text { impact } \\
{[\%]}\end{array}$ & $\begin{array}{c}\text { rather } \\
\text { unfa- } \\
\text { vourably } \\
{[\%]}\end{array}$ & $\begin{array}{l}\text { definitely } \\
\text { unfa- } \\
\text { vourably } \\
{[\%]}\end{array}$ & $\begin{array}{l}\text { difficult } \\
\text { to say } \\
{[\%]}\end{array}$ \\
\hline \multirow{6}{*}{$\underset{4}{8}$} & $18-24$ years & 20.80 & 42.10 & 18.00 & 6.20 & 3.90 & 9.00 \\
\hline & $25-34$ years & 14.60 & 46.00 & 19.70 & 13.60 & 1.00 & 5.10 \\
\hline & $35-44$ years & 17.00 & 48.40 & 18.10 & 10.40 & 2.20 & 3.80 \\
\hline & $45-54$ years & 14.80 & 44.90 & 22.20 & 8.50 & 5.10 & 4.50 \\
\hline & 55-64 years & 10.70 & 46.00 & 24.60 & 11.20 & 2.10 & 5.30 \\
\hline & 65 years and more & 9.60 & 41.60 & 18.30 & 13.70 & 3.60 & 13.20 \\
\hline \multirow{8}{*}{$\stackrel{\mathscr{\Xi}}{\stackrel{\Xi}{\Xi}}$} & Up to 500 PLN & 42.90 & 33.30 & 4.80 & 14.30 & 4.80 & 0.00 \\
\hline & 501-1,000 PLN & 14.50 & 27.60 & 34.20 & 3.90 & 3.90 & 15.80 \\
\hline & 1,001-1,500 PLN & 13.10 & 45.50 & 22.10 & 14.10 & 0.90 & 4.20 \\
\hline & $1,501-2,000$ PLN & 16.60 & 51.70 & 9.50 & 12.80 & 3.80 & 5.70 \\
\hline & $2,001-2,500$ PLN & 11.60 & 53.60 & 8.90 & 17.00 & 6.30 & 2.70 \\
\hline & 2,501-3,000 PLN & 26.90 & 43.30 & 11.90 & 10.40 & 0.00 & 7.50 \\
\hline & Over 3,000 PLN & 20.40 & 44.90 & 4.10 & 16.30 & 4.10 & 10.20 \\
\hline & Refuse to answer & 10.30 & 42.30 & 30.10 & 6.20 & 2.70 & 8.40 \\
\hline
\end{tabular}


The positive impact of European integration on the standard of living of Polish society derives not only from aid funds coming from the EU to bolster local economic growth but also from the overall social and economic processes and their effects crossing national borders. For example, when a large number of workers from the building sector left Poland, there was a lack of skilled staff during the construction boom. Consequently, wages in Poland had to slowly increase. This phenomenon also touched other sectors of the economy. And although there still is a huge gap in wages between Western and Central-Eastern Europe, then - when the market was opened - that gap narrowed slightly. Perhaps within the upcoming years the West will be able to repay a debt of gratitude for the privileges, technological advancements and social achievements of the welfare state which were provided during the Cold War under a sort of 'scare-pressure' from Central-Eastern Europe. As Claus Offe says, the social policy in the West, "especially in the fifties, would not have taken its dynamic and progressive form if it had not been challenged by the opposition system from behind the Iron Curtain. The impact of confrontation with this system onto the internal policy can be clearly seen in case of the social policy and its history of Western Germany" (Offe 1999: 270). Offe (1999: 272) adds: "At least from 1949-1961 and maybe also in the seventies, at the phase of 'full employment' in Western Germany, Eastern Germany was a permanent memento in the social policy providing innovative impulses for its Western counterpart".

And this opinion does not concern Germany only. The working class in the West during the Cold War could largely benefit from social gains thanks to the fear and pressure exerted by the "real alternative" and threats of "real socialism" on the Western political and economic establishment. When the Eastern Bloc collapsed, it led to a reduction of previously-acquired social rights in the West - since the 1990s there has been a kind of regression in the social policy and redistribution in Europe. However, for the new EU members the present status in the Western countries is still a huge step ahead when compared with Eastern European standards. And this time the West, with its labour market and legislation in the range of the social policy, can, wilfully or not, raise the level of social security within its poorer eastern neighbours.

To make it happen this policy must, both in the East and the West, enter a transnational level, which would ensure not only a common market but also common minimum wages, the same social rights for all EU citizens (not being limited by national particularism) and common social security. This is in line with the "cosmopolitan solidarity" of Ulrich Beck; it also links the issue of social justice with the cultural recognition of diversity. According to Beck (2009: 303) "only the concepts and criteria of cosmopolitan solidarity manage to duly reflect more comprehensive relations between transnational conflicts concerning inequalities, conflicts of redistribution and conflicts of recognition". To think about social Europe, it is necessary to go beyond national solidarity and its limits: capital and business crossed the national borders a long time ago. At the transnational level still there is no social 'counterweight' or political force which would be ready for such transnational redistribution.

The "cosmopolitan solidarity" perspective shows that in the process of modernisation of the European peripheries and semi-peripheries, it is not the social or economic dimension which counts but the other, less material, spheres of public life. 
The Polish respondents perceive some positive impacts of the EU on immaterial aspects of their public life. As said by Ronald Inglehart (1997), European integration satisfies not only materialistic values but also allows the emergence of, and better maintenance of, postmaterialistic values in Polish society. This is indicated by the results obtained. Within all the age categories the vast majority of the respondents think that the membership in the EU has improved the natural environment in Poland and also share the opinion that European integration has positively affected civil rights compliance (Tabs 6 and 7). While the respondents' opinions do not significantly differ according to age category, it is worth emphasising that people earning the lowest wages most frequently point to the improved civil rights compliance after Poland joined the EU (within this category up to $66 \%$ of the respondents think so).

Table 6. Respondents' age and their assessment of the impact of Poland's membership in the EU on the natural environment

\begin{tabular}{|c|c|c|c|c|c|c|c|}
\hline & \multicolumn{6}{|c|}{$\begin{array}{l}\text { Do you think that Poland's accession to the European Union } \\
\text { has impacted the natural environment rather favourably, rather } \\
\text { unfavourably or no impact was perceived? }\end{array}$} \\
\hline & & $\begin{array}{l}\text { definitely } \\
\text { favour- } \\
\text { ably }[\%]\end{array}$ & $\begin{array}{c}\text { rather } \\
\text { favour- } \\
\text { ably }[\%]\end{array}$ & $\begin{array}{l}\text { no } \\
\text { impact } \\
{[\%]}\end{array}$ & $\begin{array}{l}\text { rather } \\
\text { unfavour- } \\
\text { ably [\%] }\end{array}$ & $\begin{array}{l}\text { definitely } \\
\text { unfavour- } \\
\text { ably [\%] }\end{array}$ & $\begin{array}{l}\text { difficult } \\
\text { to say } \\
{[\%]}\end{array}$ \\
\hline \multirow{6}{*}{$\underset{8}{8}$} & $18-24$ years & 0.00 & 1.10 & 24.20 & 43.30 & 29.80 & 1.70 \\
\hline & 25-34 years & 0.50 & 2.50 & 25.30 & 44.40 & 27.30 & 0.00 \\
\hline & $35-44$ years & 0.50 & 4.90 & 17.00 & 47.80 & 29.10 & 0.50 \\
\hline & $45-54$ years & 1.70 & 3.40 & 18.80 & 42.00 & 32.40 & 1.70 \\
\hline & 55-64 years & 1.60 & 2.70 & 18.70 & 49.70 & 24.10 & 3.20 \\
\hline & $\begin{array}{l}65 \text { years } \\
\text { and over }\end{array}$ & 1.00 & 6.60 & 22.80 & 42.10 & 21.30 & 6.10 \\
\hline
\end{tabular}

Looking at Figure 4, it is clearly shown that some aspects of social life have been subject to some significant changes, according to the people surveyed. In their opinion, moral freedom, tolerance towards others and bureaucracy have increased most. In turn, during the European integration interpersonal links and Polish religiosity - as perceived by the respondents - have weakened most.

These subjective assessments are confirmed by some sociological research studies. As expressed by Aleksandra Jasińska-Kania, within all moral spheres in the past period in Poland, decreased rigorism and increased permissiveness of moral assessments followed in line with the predicted concepts of modernism and post-modernism. In spite of these changes and growing moral freedom, "when compared to other European countries Poland stands out with a relatively high level of rigorism" (Jasińska-Kania 2012: 111).

In the religious sphere as well, the respondents' feelings are reflected in sociological research studies - secularisation and privatisation are two processes which have gained 
acceleration. As Mirosława Marody and Sławomir Mandes (2012: 205) write: "these changes are not made as a result of any kind of breakthrough, though - as it results from the data - they have gained acceleration since 2005". This would mean that in everyday life the process of European integration provides Poles with many other values and patterns which effectively replace religion. As the authors summarise "religion is an area of Polish life which has lost most of its significance over the last 20 years [...], and changes within the percentage of people declaring to be religious put Poland in the group of secularising countries" (Marody, Madnes 2012: 200). In spite of these objective processes in social life, the Church has still retained numerous privileges and significant influence over national policies. Still, the creeping secularisation will not lead to cultural and political enlightenment.

Table 7. Respondents' age and income and their assessment of the impact of Poland's membership in the EU on civil rights compliance

\begin{tabular}{|c|c|c|c|c|c|c|c|}
\hline & \multicolumn{6}{|c|}{$\begin{array}{l}\text { Do you think that Poland's accession to the European Union } \\
\text { has impacted civil rights compliance rather favourably, rather } \\
\text { unfavourably or no impact was perceived? }\end{array}$} \\
\hline & & $\begin{array}{l}\text { definitely } \\
\text { favour- } \\
\text { ably }[\%]\end{array}$ & $\begin{array}{l}\text { rather } \\
\text { favour- } \\
\text { ably }[\%]\end{array}$ & $\begin{array}{c}\text { no } \\
\text { impact } \\
{[\%]}\end{array}$ & $\begin{array}{c}\text { rather } \\
\text { unfa- } \\
\text { vourably } \\
{[\%]}\end{array}$ & $\begin{array}{l}\text { definitely } \\
\text { unfa- } \\
\text { vourably } \\
{[\%]}\end{array}$ & $\begin{array}{c}\text { difficult } \\
\text { to say } \\
{[\%]}\end{array}$ \\
\hline \multirow{6}{*}{$\underbrace{\circ}_{i}$} & $18-24$ years & 1.70 & 11.20 & 44.40 & 27.00 & 12.40 & 3.40 \\
\hline & 25-34 years & 1.50 & 14.10 & 50.50 & 25.80 & 7.60 & 0.50 \\
\hline & $35-44$ years & 3.30 & 15.90 & 41.80 & 29.70 & 7.70 & 1.60 \\
\hline & 45-54 years & 5.10 & 17.60 & 38.10 & 30.10 & 7.40 & 1.70 \\
\hline & 55-64 years & 4.30 & 20.30 & 34.20 & 33.70 & 7.00 & 0.50 \\
\hline & 65 years and over & 4.10 & 16.20 & 41.60 & 22.80 & 6.10 & 9.10 \\
\hline \multirow{8}{*}{ 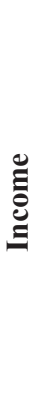 } & Up to 500 PLN & 4.80 & 4.80 & 23.80 & 38.10 & 28.60 & 0.00 \\
\hline & 501-1,000 PLN & 1.30 & 14.50 & 34.20 & 28.90 & 11.80 & 9.20 \\
\hline & 1,001-1,500 PLN & 4.20 & 22.10 & 41.80 & 21.60 & 8.90 & 1.40 \\
\hline & 1,501-2,000 PLN & 4.30 & 24.60 & 38.40 & 26.10 & 5.20 & 1.40 \\
\hline & 2,001-2,500 PLN & 5.40 & 16.10 & 44.60 & 25.90 & 8.00 & 0.00 \\
\hline & 2,501-3,000 PLN & 4.50 & 16.40 & 40.30 & 31.30 & 7.50 & 0.00 \\
\hline & Over 3,000 PLN & 4.10 & 16.30 & 36.70 & 34.70 & 8.20 & 0.00 \\
\hline & Refuse to answer & 1.60 & 8.10 & 46.60 & 31.40 & 7.00 & 5.10 \\
\hline
\end{tabular}

The decline in religiosity and increasingly market-driven relations between individuals and the outside world have also led to some impairment and transformation of social bonds. Increasing loneliness and an increasing number of one-person households are other phenomena which have intensified under the system transformation. 


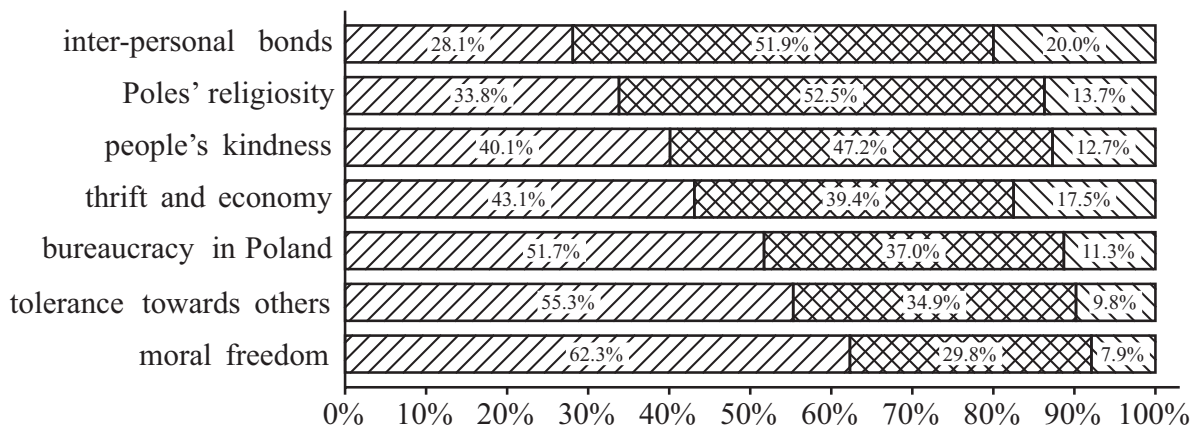

Q7 has increased

Figure 4. Impact of Poland's integration with the EU on some selected spheres of public life,

$$
N=1118
$$

\section{POLAND SEEMS TO BE A PROBLEM AND EUROPE, ITS SOLUTION}

In spite of these ongoing changes Poles still perceive a huge gap which separates them from the 'public order' of Western Europe. The situation in all areas of collective life in Poland is less favourable than that in the West. The assessment of the health care system, offices and institutions and also the justice system and police in Poland turns out negative when compared to their European counterparts (Tab. 8).

Table 8. Assessment of operation of selected Polish institutions when compared to their European counterparts

\begin{tabular}{|l|c|c|c|c|}
\hline $\begin{array}{l}\text { When assessing institutions - which of them } \\
\text { operate better, worse or at the same level in } \\
\text { Poland than in other European countries? }\end{array}$ & $\begin{array}{c}\text { Better } \\
{[\mathbf{\%}]}\end{array}$ & $\begin{array}{c}\text { At the } \\
\text { same level } \\
{[\%]}\end{array}$ & $\begin{array}{c}\text { Worse } \\
{[\%]}\end{array}$ & $\begin{array}{c}\text { Difficult } \\
\text { to say [\%] }\end{array}$ \\
\hline Health care & 9.1 & 34.2 & 53.6 & 3.1 \\
\hline Courts and Justice & 6.5 & 45.9 & 37.3 & 10.3 \\
\hline Police & 9.7 & 40.4 & 39.3 & 10.6 \\
\hline Public institutions & 7.2 & 28.3 & 49.8 & 14.7 \\
\hline Schools & 13.7 & 28.3 & 35.5 & 22.5 \\
\hline
\end{tabular}

The criticism of Polish institutions is not restricted, however, to official institutional governance but also covers the sphere of citizens' behaviours. Poles are aware of their poor self-organisation: they know that they demonstrate and go on strike less often, vote less frequently and have weaker trade-union organisations when compared to the citizens of Western Europe (Tab. 9). 
Table 9. Active citizenship in Poland when compared to the countries of Western Europe

\begin{tabular}{|l|c|c|c|c|}
\hline \multicolumn{1}{|c|}{$\begin{array}{c}\text { Poles compared to people living } \\
\text { in Western Europe }\end{array}$} & $\begin{array}{c}\text { More } \\
\text { often [\%] }\end{array}$ & $\begin{array}{c}\text { At the } \\
\text { same level } \\
{[\%]}\end{array}$ & $\begin{array}{c}\text { Less } \\
\text { frequently } \\
{[\%]}\end{array}$ & $\begin{array}{c}\text { Difficult } \\
\text { to say [\%] }\end{array}$ \\
\hline Protest and demonstrate & 15.0 & 38.5 & 34.7 & 11.8 \\
\hline Strike and stand up for workers' rights & 16.8 & 45.7 & 24.3 & 13.1 \\
\hline Join trade unions & 13.6 & 43.3 & 23.9 & 19.2 \\
\hline Are made redundant from work & 25.8 & 39.3 & 18.9 & 16.1 \\
\hline Join social organisations & 12.5 & 35.8 & 29.1 & 22.6 \\
\hline Participate in elections & 7.4 & 33.9 & 41.1 & 17.5 \\
\hline
\end{tabular}

However, the worst is to come when we compare wages earned by Poles and residents of Western Europe: up to $88 \%$ of the surveyed people think that people in Poland earn less than in the West while working more (36\% of respondents think that Poles work more than their Western counterparts). They go on holidays less frequently and have less influence on the government/authorities and their decisions. This is a sad - but very realistic - picture of the state of affairs (Tab. 10).

Samir Amin - criticising the European Union for developing only its economic aspect (the integrated market) - calls for strengthening its political and social dimensions. Formally, the countries of Central-Eastern Europe belong to the EU but when asked if "Eastern Europe can be incorporated into the European project", Amin answered:

"Maybe, but only then when Western Europeans - within intra-European relations - do not see their Eastern partners as "Latin Americans"" (Amin 2004: 163). More than 10 years after the accession to the EU, Poland still continues to be a source of cheap labour, as it is considered so by the vast majority of Polish society, regardless of age (Tab. 11).

Low wages, when compared to those of Western Europe, go hand in hand with a sense of having no influence over the social reality despite the formal democratic system. Compared to the citizens of Western Europe, Poles feel a lower sense of having any impact on the government/authorities and their decisions: in all age categories the respondents believe that the influence of citizens on the authorities is higher in the West (Tab. 10). However, it is more surprising to compare the results of research studies taken from the late 1980s with the current social moods. In $1988,85 \%$ of the Polish society negatively answered the question: "Do you think that people like you feel a sense of having any impact on the affairs of your country?" In 1990, 70\% of the respondents gave negative answers and in 2013 it was up to $79 \%$ (only $19 \%$ of all the respondents felt that they had any impact on the affairs of the country) (CBOS 2013). The variance between the final period of the Communist times in Poland and the current situation is almost non-existent at the level of the citizens' sense of subjectivity. Therefore, David Ost was right when he wrote:

However, if we treat democracy like something more than just the procedural principles, like the inclusive system [...] - where all citizens are legitimate members of the community, and working people are involved in the economic system - then today's Poland is hardly a democratic system. 
[...] In order to understand the process of democratisation in Eastern Europe, we need be fully aware of such variances within the democratic capitalism. Instead of 'giving points' for ensuring the fundamental rights of an individual, it is high time to treat people living in Eastern Europe as citizens of other democratic countries and to explore the character and quality of democracy which prevails in these countries (Ost 2007: 380-381).

Table 10. Life styles of Poles and citizens of Western Europe

\begin{tabular}{|l|c|c|c|c|}
\hline \multicolumn{1}{|c|}{$\begin{array}{c}\text { Poles compared to people living } \\
\text { in Western Europe }\end{array}$} & More [\%] & $\begin{array}{c}\text { At the same } \\
\text { level [\%] }\end{array}$ & Less [\%] & $\begin{array}{c}\text { Difficult } \\
\text { to say [\%] }\end{array}$ \\
\hline Earn & 5.8 & 5.3 & 87.7 & 1.2 \\
\hline Work & 36.0 & 38.6 & 20.3 & 5.0 \\
\hline Go on holidays & 8.2 & 35.8 & 40.9 & 15.1 \\
\hline $\begin{array}{l}\text { Have an impact on the government / authori- } \\
\text { ties and their decisions }\end{array}$ & 6.7 & 31.9 & 36.5 & 24.9 \\
\hline Get divorced & 15.7 & 28.1 & 24.7 & 31.5 \\
\hline
\end{tabular}

Table 11. Age and wages in Poland and Western Europe

\begin{tabular}{|c|c|c|c|c|c|}
\hline & & \multicolumn{4}{|c|}{$\begin{array}{c}\text { Do Poles - when compared to people living in Western Europe - } \\
\text { earn more, less or the same? }\end{array}$} \\
\hline & & more $[\%]$ & the same [\%] & less $[\%]$ & $\begin{array}{c}\text { difficult to say } \\
{[\%]}\end{array}$ \\
\hline \multirow{6}{*}{$\stackrel{8}{4}$} & 18-24 years & 5.60 & 5.10 & 88.20 & 1.10 \\
\hline & $25-34$ years & 6.60 & 2.50 & 89.90 & 1.00 \\
\hline & 35-44 years & 4.40 & 7.10 & 88.50 & 0.00 \\
\hline & 45-54 years & 5.10 & 5.10 & 89.20 & 0.60 \\
\hline & 55-64 years & 5.90 & 7.50 & 86.10 & 0.50 \\
\hline & 65 years and more & 7.10 & 4.60 & 84.80 & 3.60 \\
\hline
\end{tabular}

Table 12. Change in Poles' capabilities after the accession to the EU

\begin{tabular}{|l|c|c|c|c|c|}
\hline \multicolumn{1}{|c|}{$\begin{array}{c}\text { Changes in citizens' } \\
\text { capabilities }\end{array}$} & $\begin{array}{c}\text { Definitely } \\
\text { better } \\
{[\mathbf{\%}]}\end{array}$ & $\begin{array}{c}\text { Rather } \\
\text { better } \\
{[\mathbf{\%}]}\end{array}$ & $\begin{array}{c}\text { No } \\
\text { change } \\
{[\%]}\end{array}$ & $\begin{array}{c}\text { Rather } \\
\text { worse [\%] }\end{array}$ & $\begin{array}{c}\text { Definitely } \\
\text { worse [\%] }\end{array}$ \\
\hline To start a business & 22.8 & 50.3 & 24.8 & 2.0 & 0.2 \\
\hline To establish an association & 15.0 & 48.7 & 34.2 & 1.8 & 0.3 \\
\hline To write a civil complaint & 10.9 & 41.9 & 42.4 & 4.0 & 0.8 \\
\hline To fight for labour rights at work & 9.2 & 33.3 & 43.7 & 11.4 & 2.4 \\
\hline
\end{tabular}




\section{ALTERNATIVE SCENARIOS? THE STRUGGLE GOES ON!}

The modernised European Union is the only viable alternative - as there is no other on the horizon - to the Polish reality under its current semi-peripheral capitalism. It brings hopes for a better life, advancement of civilisation and the development of social self-awareness. Poles perceive that upon Poland's accession to the European Union their social skills have increased: more people feel able to set up a business, establish an association, write a civil complaint and even fight for labour rights more skilfully (Tab. 12). And although in reality the respondents do not fully share these feelings, the fact is that the European integration and its effects strengthen the social capital of its citizens.

According to Robert Putnam both social capital and civic engagement enable people to solve collective problems more easily, to expand, in a number of ways, their awareness of 'interconnection' of human lives or reduce the time and resources needed to conduct standard social interactions. Among the factors which strengthen this social capital in America, Putnam (2008) enumerates the following: less pursuit of money and a calmer life, an individual's deeper 'rootedness' in one's local community, and greater independence from being pressurised by television and other channels of mass communication. For people living in Central and Eastern Europe, the impact of West-European experience and patterns of behaviour can be added to this list.

The vast majority of the respondents support further European integration: up to $63 \%$ of them support strengthening Poland's links with the European Union and as little as approximately $23 \%$ believe that the integration process has already gone too far. The following question arises: what does a model of integration mean to them and what is hidden under their opinions? The obtained study results show that Western Europe is still a place for "a better life", more civilised and regarded as the "centre" by peripheral and semi-peripheral neighbours from the eastern part of the continent. In other words: the area to the west of the Elbe River is quite commonly recognised in Poland as a sourcing ground of modernisation. With the concept of Frederick Jameson, who referred the term of modernisation primarily to the material and economic sphere and complemented it with the idea of modernism covering the socio-cultural dimension, one may get the impression that in case of the current integration the authorities and business elites in Poland have forgotten this second component. It includes social emancipation and socio-civic achievements being the result of over 200 years of social struggles in Western Europe. Only the combination of modernisation and modernism - according to Jameson (1991) - would enable bringing social order to modern times. And that is how it seems to be concerning the subject of social aspirations in Poland.

This is in line with the postulate by Jurgen Habermas to complement the current "system integration" with "social integration". The first takes place at the administrative, economic and governmental levels. The second is conducted by means of values and agreements and takes place within the international civil society (Habermas 1993). So far the enlarged European Union with the new countries from Central and Eastern Europe has been - too often - limited to "system integration", which does not undermine hierarchical relations between the centre and the periphery of the capitalist system.

In spite of all the shortcomings of the current form of European integration, today it is difficult to image any other alternative to the Polish presence in the EU. Almost half of the 
respondents (48.5\%) reject the hypothetical idea of being outside of the EU and maintaining closer cooperation with the countries of Eastern Europe (Fig. 5). Also the idea of Poland's absence from the EU along with close cooperation with the United States is not well received: only $22.3 \%$ of the respondents support it and up to $38.3 \%$ is against it (Fig. 6). The 'attractiveness' of the United States after the last two decades has decreased quite a lot in Poland, and this is due to several reasons. It is partly as a result of the wars in Iraq and Afghanistan (also involving Polish soldiers), as its participation in both of these conflicts was not accepted by the majority of Poles. And Western Europe is more attractive in economic terms; moreover, it is situated 'on the doorstep' and no passports or visas are needed. Going to the United States means holding a passport and a visa and the whole bureaucratic 'ritual' people were engaged in when going on a trip abroad in the communist times.

Out of the three alternative scenarios, the scenario of Poland keeping its independence while not joining the EU gained the largest support. Here the voting went almost equally: $35.7 \%$ reject this project, while it is supported by $34.2 \%$ of the respondents (Fig. 7). However, in the today's global world the final idea seems to be the least realistic. In the early 1990s the concept of a neutral country appeared to be quite a serious option. Jerzy Wiatr mentions that at the beginning of the system transformation in Central and Eastern Europe the postcommunist leaders had no clear idea on how to shape the position of these countries in European and world politics after being freed from the Soviet domination. Therefore, for this reason, among others, "the concept of neutrality [...] as a result of mistrust for the Western guarantees of security and fears of German domination, was favoured among politicians in charge of governments in the post-communist countries" (Wiatr 2006: 339-340). However, it was just after 1991 (i.e. after the collapse of the Soviet Union) when the general direction of changes in the international system was outlined. Poland became an associate member of the European Union in 1994; in 1998 it began accession negotiations, in 2003 it held an accession referendum, and in 2004 the EU was joined by new members from Central and Eastern Europe (along with Poland in 2004 the EU was formally joined by, among others, Hungary, the Czech Republic, Slovakia, Estonia, Latvia, and Lithuania). Throughout this period in Poland there were no major disagreements on European integration between the government, the opposition and civil society. However, there is still an open issue as to the model of interactions between the 'old' EU and the new members from the East.

In the mid-1990s Ira Katznelson (2006: 51) wrote that "prior to the collapse of communism, Western European and North American liberal political ethics had drawn strength from the existence of rotten socialism in the East while dissident anti-bolshevism in communist Europe had grown on liberalism in the West". Today the former Eastern Europe has still continued to look at the West longingly, though less romantically and more realistically. However, Western Europe has been slightly afraid of an invasion of a cheap workforce from Central and Eastern Europe; it also fears the rising tide of nationalism which is occurring both in Eastern Europe (as a result of no social stability and hence growing frustration) and in Western Europe (concerns over immigration and threats to local labour markets). Former mutual influences and hopes were replaced by concerns on the one hand and 'cold calculations' on the other. Therefore, today - more than ever - further European integration and mutual cooperation is needed, rather than building new walls and rebuilding former borders. For this to happen, 
the current "Europe of banks and social cuts" must be replaced by "a Europe of citizens" being more rebellious, courageous, with more extensive imagination, sensitivity and social empathy. This cannot be done without creating bridges of solidarity between the eastern and western areas of Europe. This process must cover not only the economic dimension but also the political, social and civic ones. The European dream to create a better and just world can continue to inspire other parts of the world. The joint struggle of European societies and citizens is not finished. It still goes on.

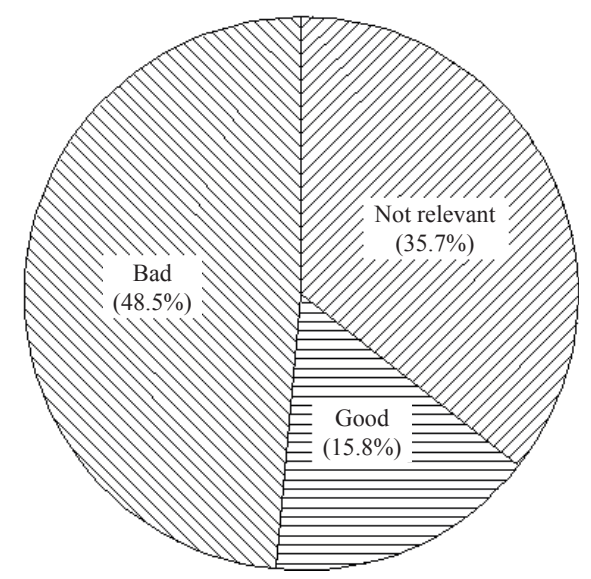

Figure 5. What, in your opinion, would be the situation of Poland if it was outside of the EU and closely cooperated with its neighbours from Eastern Europe?

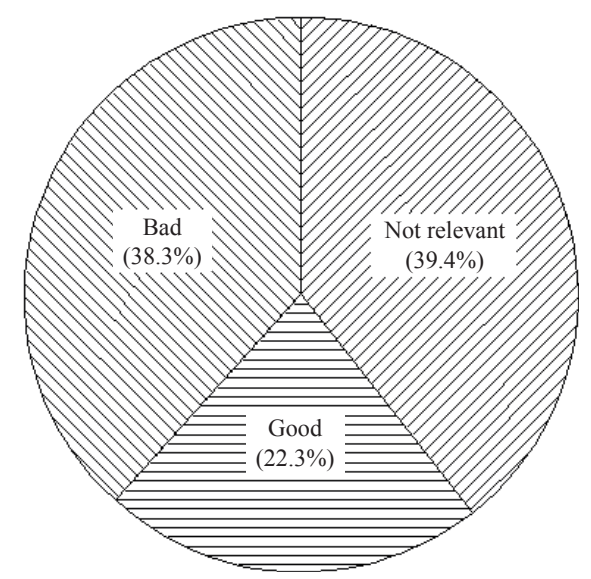

Figure 6. What, in your opinion, would be the situation of Poland if it was outside of the EU and closely cooperated with the United States? 


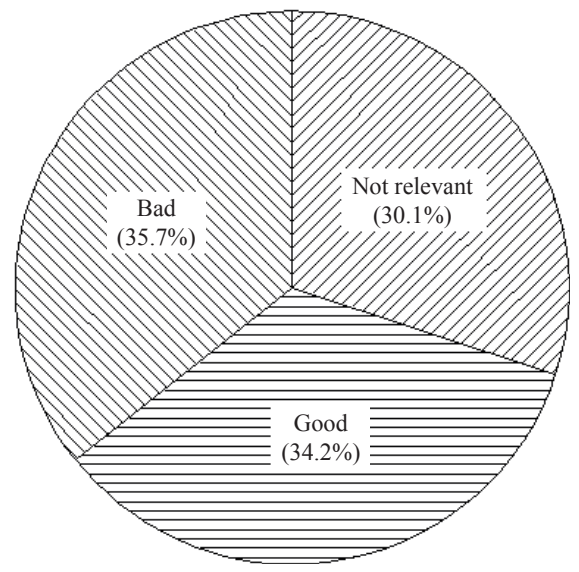

Figure 7. What, in your opinion, would be the situation of Poland if it was outside of the EU and kept its independence

\section{REFERENCES}

Amin, Samir. 2004. Zmurszały kapitalizm, trans. Ryszard Wojna and Zbigniew Kowalewski, Warszawa: Wydawnictwo Dialog.

Beck, Ulrich. and Edgar Grande. 2009. Europa kosmopolityczna. Społeczeństwo i polityka $w$ drugiej nowoczesności, trans. Aleksander Ochocki, Warszawa: Wydawnictwo Naukowe Scholar.

CBOS. 2013. Poczucie wptywu na sprawy publiczne, [survey], September.

Chomsky, Noam. 2003. Hegemony or Survival. America's Quest for Global Dominance. New York: Henry Holt.

Habermas, Jurgen. 1993. Obywatelstwo a tożsamość narodowa: rozważania nad przyszłościa Europy, trans. Barbara Markiewicz, Warszawa: IFiS PAN.

Inglehart, Ronald. 1997. Modernisation and Post-modernization. Cultural, Economic and Political Change in 43 Societies, Princeton, NJ: Princeton University Press.

Jameson, Fredric. 1991. Postmodernism or Cultural Logic of Late Capitalism, London: Verso Books.

Jasińska-Kania, Aleksandra. 2012. Między rygoryzmem a permisywnościq: przemiany moralności w Polsce $i$ w Europie, in: A. Jasińska-Kania (ed.), Wartości i zmiany. Przemiany postaw Polaków w jednoczqcej się Europie, Warszawa: Wydawnictwo Naukowe Scholar, pp. 105-130.

Katznelson, Ira. 2006. Krzywe koło liberalizmu: listy do Adama Michnika [Liberalism's Crooked Circle: Letters to Adam Michnik], trans. Łukasz Nysler, Andrzej Orzechowski and Lotar Rasiński, Wrocław: Wydawnictwo Naukowe Dolnośląskiej Szkoły Wyższej Edukacji TWP. 
Kołodko, Grzegorz. 2010. Świat na wyciagnięcie myśli, Warszawa: Prószyński i S-ka.

Kowalik, Tadeusz. 2010. Kryzys systemu w perspektywie alterglobalizmu [Crisis of the system in alterglobalism], in: Grzegorz Kołodko (ed.), Globalizacja, kryzys i co dalej?, Warszawa: Poltext, pp. 57-70.

Marody, Mirosława and Sławomir Mandes. 2012. Przemiany polskiej religijności, in: A. Jasińska-Kania (ed.), Wartości i zmiany. Przemiany postaw Polaków w jednoczacej się Europie, Warszawa: Wydawnictwo Naukowe Scholar, pp. 191-206.

Offe, Claus. 1999. Drogi transformacji. Doświadczenia wschodnioeuropejskie $i$ wschodnioniemieckie, trans. Zbigniew Pucek, Warszawa - Kraków: Wydawnictwo Naukowe PWN.

Ost, David. 2007. Klęska „Solidarności”. Gniew i polityka w postkomunistycznej Europie, Warszawa: Wydawnictwo Muza SA.

Putnam, Robert. 2008. Samotna gra w kręgle: upadek i odrodzenie wspólnot lokalnych w Stanach Zjednoczonych, trans. Przemysław Sadura and Sebastian Szymański, Warszawa: Wydawnictwa Akademickie i Profesjonalne.

Sowa, Jan. 2011. Fantomowe ciało króla. Peryferyjne zmagania z nowoczesna forma, Kraków: Universitas.

Wallerstein, Immanuel. 2007. Analiza systemów-światów. Wprowadzenie, trans. Katarzyna Gawlicz and Marcin Starnawski, Warszawa: Wydawnictwo Dialog.

Wiatr, Jerzy. 2006. Europa pokomunistyczna. Przemiany państw i spoleczeństw po 1989 roku, Warszawa: Wydawnictwo Naukowe Scholar.

\section{INTEGRACJA EUROPEJSKA Z PERSPEKTYWY WSCHODNIOEUROPEJSKICH PÓŁPERYFERII UNII EUROPEJSKIEJ. PRZYPADEK POLSKI}

Artykuł prezentuje oceny i opinie społeczeństwa polskiego na temat skutków członkostwa w Unii Europejskiej. W 2014 roku minęło dziesięć lat, kiedy większość krajów Europy Środkowo-Wschodniej zostało częścią Unii Europejskiej. To dobra okazja do refleksji nad rolą i miejscem krajów postkomunistycznych w obecnym porządku światowym. Autor artykułu sugeruje, że przydatnym narzędziem do zrozumienia sytuacji tego regionu może być perspektywa teorii postkolonialnych czy też teoria zależności systemu-świata.

Wskazują na to również wyniki badań, które ukazują, że respondenci dostrzegają we wszystkich wymiarach życia publicznego dystans, jaki dzieli Polskę od standardów krajów Europy Zachodniej. Nie chodzi tylko o sferę socjalną, ale także o ocenę ładu instytucjonalnego czy aktywność i samoświadomość obywatelską. Pomimo trudności i kryzysów, jakie przelewają się przez kraje Unii Europejskiej (choćby sytuacja w Grecji czy w Portugalii) społeczeństwo polskie - jak pokazują wyniki badań - nadal postrzega dalszą integrację europejską jako sposób na rozwiązanie swoich problemów.

Keywords: transformacja systemowa, integracja europejska, półperyferyjny kapitalizm, Wschód-Zachód, ocena Unii Europejskiej 